\title{
Highly pathogenic avian influenza virus infection in chickens but not ducks is associated with elevated host immune and pro-inflammatory responses
}

\author{
Suresh V Kuchipudi ${ }^{1 *}$, Meenu Tellabati ${ }^{1}$, Sujith Sebastian', Brandon Z Londt ${ }^{2}$, Christine Jansen ${ }^{3}$, \\ Lonneke Vervelde ${ }^{3,4}$, Sharon M Brookes ${ }^{2}$, lan H Brown², Stephen P Dunham and Kin-Chow Chang
}

\begin{abstract}
Highly pathogenic avian influenza (HPAl) H5N1 viruses cause severe infection in chickens at near complete mortality, but corresponding infection in ducks is typically mild or asymptomatic. To understand the underlying molecular differences in host response, primary chicken and duck lung cells, infected with two HPAI H5N1 viruses and a low pathogenicity avian influenza (LPAI) H2N3 virus, were subjected to RNA expression profiling. Chicken cells but not duck cells showed highly elevated immune and pro-inflammatory responses following HPAl virus infection. HPAI H5N1 virus challenge studies in chickens and ducks corroborated the in vitro findings. To try to determine the underlying mechanisms, we investigated the role of signal transducer and activator of transcription-3 (STAT-3) in mediating pro-inflammatory response to HPAIV infection in chicken and duck cells. We found that STAT-3 expression was down-regulated in chickens but was up-regulated or unaffected in ducks in vitro and in vivo following H5N1 virus infection. Low basal STAT-3 expression in chicken cells was completely inhibited by H5N1 virus infection. By contrast, constitutively active STAT-3 detected in duck cells was unaffected by H5N1 virus infection. Transient constitutively-active STAT-3 transfection in chicken cells significantly reduced pro-inflammatory response to H5N1 virus infection; on the other hand, chemical inhibition of STAT-3 activation in duck cells increased pro-inflammatory gene expression following $\mathrm{H} 5 \mathrm{~N} 1$ virus infection. Collectively, we propose that elevated pro-inflammatory response in chickens is a major pathogenicity factor of HPAI H5N1 virus infection, mediated in part by the inhibition of STAT-3.
\end{abstract}

\section{Introduction}

Avian influenza A viruses continue to spread globally causing millions of poultry deaths and are significant zoonotic pathogens [1]. In particular, Eurasian lineage highly pathogenic avian influenza (HPAI) H5N1 virus infection causes severe disease in humans with a fatality rate of about 60\% [2]. Most human influenza pandemics of the $20^{\text {th }}$ century had been caused by influenza A viruses (IAVs) that originated, either wholly or in part, from avian influenza A viruses [3]. Ducks and waterfowl are reservoirs for most IAVs, including the hemagglutinin (HA)

\footnotetext{
* Correspondence: suresh.kuchipudi@nottingham.ac.uk

'School of Veterinary Medicine and Science, University of Nottingham, Sutton Bonington Campus, College Road, Loughborough, Nottingham, Leicestershire LE12 5RD, UK

Full list of author information is available at the end of the article
}

and neuraminidase (NA) subtypes that have caused previous human pandemics [4]. Despite being susceptible to infection with a wide range of IAVs, such birds often show little or no clinical signs $[5,6]$.

In contrast, most HPAI H5N1 virus strains produce very severe disease in chickens, turkeys and quails often causing up to $100 \%$ mortality within $2-3$ days $[7,8]$. With their natural resistance, ducks support genetic reassortment of influenza viruses providing a mechanism of evolution of genetically diverse IAVs including HPAI H5N1 viruses [9-11]. The rapid onset of fatal disease in chickens and no evidence of clinical disease in ducks suggests that there are potential differences in the innate immune mechanisms between these two important avian hosts. Recent evidence shows that the resistance of ducks to HPAI virus infection is not absolute. Contemporary 
Eurasian lineage HPAI H5N1 viruses have caused large numbers of deaths in both poultry and water fowl including ducks. Experimental infection of Pekin ducks (Anas platyrhynchos) with a HPAI H5N1 clade 2.2.1 virus (A/turkey/Turkey/1/2005) causes fatal infection [12], suggesting that certain clades of contemporary Eurasian lineage HPAI H5N1 viruses are able to overcome the natural innate resistance of ducks.

The unusual severity of HPAI H5N1 virus infection in humans, in contrast to seasonal $\mathrm{H} 3 \mathrm{~N} 2$ or $\mathrm{H} 1 \mathrm{~N} 1$ influenza viruses, has been regarded to be due to hyper-acute induction of pro-inflammatory cytokines often referred as hypercytokinemia or cytokine storm [13-15]. Pigs show mild or no clinical signs following HPAI H5N1 virus infection [16]. We recently showed that the innate resistance of pigs to HPAI H5N1 virus is mediated through reduced pro-inflammation and infectious virus release [17]. These findings indicate that dysregulation of host pro-inflammatory response to infection is a key contributing factor to the morbidity and mortality of virulent influenza virus infections. Similarly a recent study found that excessive delayed inflammatory cytokine responses may contribute to the severe pathogenicity of HPAI H7N1 in chickens [18]. However, the pathophysiology of $\mathrm{H} 5 \mathrm{~N} 1$ virus infection in chickens and ducks remains unclear. To further our molecular understanding of the pathogenesis of HPAI H5N1 virus infection in chickens and ducks, we examined differences in host gene response to IAV infection between chickens and ducks in vitro (in lung cells) and in vivo.

\section{Materials and methods}

\section{Viruses}

A low pathogenicity avian influenza virus (A/mallard duck/England/7277/06, referred to as LPAI-H2N3), a classical HPAI H5N1 virus strain (A/turkey/England/5092/91, referred to as H5N1-tyEng91) and a contemporary Eurasian lineage clade 2.2.1 HPAI H5N1 virus (A/turkey/Turkey/1/05, referred to as H5N1-tyTR05) were used in this study. While the "classical" H5N1 virus typically causes non-lethal infection in ducks [19], the contemporary Eurasian lineage (clade 2.2.1) H5N1 virus may cause severe disease with mortality in ducks [12]. All viruses were grown in 10-day-old embryonated chicken eggs by allantoic inoculation.

\section{Primary cells and virus infection}

Primary cell cultures were isolated from lungs of 4-weekold broiler chickens and 4-week-old Pekin ducks as previously described [20]. Cells were grown in collagen coated cell culture flasks (Costar, Corning, UK) in Dulbecco's Modified Eagle's Medium (DMEM) and Ham's F12 (1:1) supplemented with $2 \%$ chicken embryo extract (Biosera, Uckfield, UK), 5\% fetal bovine serum, $1 \%$ insulin-transferrin selenium (Life Technologies, Paisley, UK) and antibiotics. Monolayers of primary cells in 6 well cell culture plates (Costar) were infected with LPAI or HPAI viruses at multiplicity of infection (MOI) of 1.0. Three wells of avian cells were used for each virus infection. Mock infections were performed without virus in triplicate wells for each cell type. Cells were rinsed with phosphate buffered saline (PBS) and infected with appropriate amount of the virus in serum free infection medium comprising $2 \%$ Ultroser G (Pal Biosepra, Cedex, France), 500 ng/mL TPCK trypsin (Sigma-Aldrich, Dorset, UK) and antibiotics in Ham's F12 medium. After $2 \mathrm{~h}$ incubation with the virus, the cells were washed three times with PBS and fresh medium was added.

\section{Immuno-staining for virus nucleoprotein (NP)}

To determine the pattern of virus infection, virus and mock infected cells were fixed in acetone:methanol at 6 hours post-infection (hpi) and were subjected to viral nucleoprotein detection by a primary mouse monoclonal antibody (Abcam, Cambridge, UK) followed by visualization with Envision + system-HRP (DAB; Dako, Ely, UK). Cell culture supernatants form infected cells were titrated in MDCK cells to determine focus forming units (ffu) using an immuno-cytochemical focus assay as previously described [20].

\section{Microarray gene expression profiling}

At 24 hpi, total RNA from each well was extracted using RNeasy Plus Mini - QIAshredder Kit (Qiagen, Manchester, UK) and the quality of the total RNA samples was determined using a RNA 6000 nano kit (Agilent 2100 Bioanalyzer, Agilent Technologies, Stockport, UK) following the manufacturer's instructions. Microarray expression analysis was carried out using GeneChip chicken genome arrays (Affymetrix, High Wycombe, UK). Duplicate RNA samples from each of virus or mock infected chicken and duck cells were used for microarray analysis and a total of 16 array chips ( 3 viruses $\times 2$ avian species $\times$ duplicate, plus 2 chicken and 2 duck mock infected) were used in the study.

Microarray expression data were analyzed using GeneSpring GX11 expression analysis software (Agilent Technologies) [21,22]. Functional clustering of data was carried out using DAVID bioinformatics resources version $6.7[23,24]$.

To take into account the specificity of heterologous hybridization (between labelled duck targets on chicken probes), a well-established analytical tool was used which involved the hybridization of duck genomic DNA to the chicken chip to establish specific probe binding for duck transcriptome analysis using chicken GeneChip arrays.

Cross species array analysis was performed by generating a probe masking file to select probe-sets on the 
chicken chip for subsequent duck transcriptome analyses if the probe-set was represented by perfect match (PM) probes with duck gDNA hybridization intensities above an experimentally set threshold [25-27]. An additional file shows the detailed protocols of microarray expression study including the cross species hybridization data analysis (see Additional file 1).

\section{Quantitative reverse transcription PCR (qRT-PCR) for viral and host genes}

Viral RNA was extracted from culture media using QIAamp Viral RNA Mini Kit (Qiagen). One-step qRT-PCR to quantify influenza viral matrix gene was performed as previously described [20]. Based on the comparison of global gene expression profiles of chicken and duck cells, key proinflammatory and antiviral genes were selected and validated by qRT-PCR using the same total RNA samples as that used for the microarray experiment.

Oligonucleotide primers and hydrolysis probes for TaqMan assays were designed from published sequences using Primer Express software version 3.0.1 (Applied Biosystems, Life Technologies). All primers were provided by Eurofins Genomics (Edersberg, Germany) and all probes were supplied by Sigma Aldrich. Primer and probe sequences are shown in Table 1. qRT-PCR assays for lipopolysaccharide induced TNF alpha factor (LITAF) and STAT-3 genes were performed using SYBR green method using same set of primers for both chicken and duck. Melting curve analysis was performed to ensure the specificity of the SYBR green PCR. qRT-PCR of cDNA samples converted from total RNA (Superscript III First-strand cDNA synthesis system, Life Technologies) was performed on a the LightCycler 480 (Roche, Burges Hill, UK), and using a relative standard curve method normalized to 185 ribosomal RNA (18SrRNA) expression.

\section{HPAI H5N1 virus challenge in chickens and ducks}

Three-week-old Lohmann Brown chickens kept in containment level 3 facilities (AHVLA, Weybridge) were infected with HPAI H5N1-tyTR05 virus. Chickens were inoculated intranasally and intraocularly with $0.1 \mathrm{~mL}$ of $1 \times 10^{6}$ EID $_{50}$ virus diluted in PBS. Birds were killed at $24 \mathrm{~h}$ after infection (three birds each from virus and control groups), lung and spleen tissues were collected and stored at $-80{ }^{\circ} \mathrm{C}$ prior to RNA extraction. Threeweeks- old Pekin ducks were inoculated with $0.1 \mathrm{~mL}$ of $1 \times 10^{6} \mathrm{EID}_{50}$ of H5N1-tyTR05 virus intranasally and intraocularly. Birds were killed humanely at 24 hpi (three birds each from virus and control groups), lung and spleen tissues were collected and stored at $-80{ }^{\circ} \mathrm{C}$ prior to RNA extraction. Tissues were homogenized using GentleMacs Dissociator (Miltenyi Biotec, Bisley, UK) and total RNA was extracted from the homogenized tissues using RNeasy Mini-Kit (Qiagen) following the

\section{Table 1 Primer and probe sequences for quantitative reverse transcription PCR assays}

\begin{tabular}{|c|c|c|c|}
\hline Gene & GenBank acc. No & Primer sequence & Probe sequence \\
\hline \multicolumn{4}{|l|}{ Chicken } \\
\hline \multirow[t]{2}{*}{ 18S rRNA } & AF173612.1 & Fwd :TGTGCCGCTAGAGGTGAAATT & $5^{\prime}$ (6FAM) TTGGACCGGCGCAAGACGAAC 3' (TAMRA) \\
\hline & & Rev: TGGCAAATGCTITCGCTTT & \\
\hline \multirow[t]{2}{*}{ IL-6 } & EU170468 & Fwd :CACGATCCGGCAGATGGT & 5' (6FAM)ATAAATCCCGATGAAGTGGTCATCC 3' (TAMRA) \\
\hline & & Rev: TGGGCGGCCGAGTCT & \\
\hline \multirow[t]{2}{*}{ IL-8 /CXCLi1 (K60) } & NM_205018.1 & Fwd :CCCTCGCCACAGAACCAA & $5^{\prime}$ (6FAM)CCCAGGTGACACCCGGAAGAAACA 3' (TAMRA) \\
\hline & & Rev: CAGCCTTGCCCATCATCTTT & \\
\hline \multirow[t]{2}{*}{ IFN-a } & EU367971 & Fwd :CTTCCTCCAAGACAACGATTACAG & 5' (6FAM)CCTGCGCCTGGGAACACGTCC 3' (TAMRA) \\
\hline & & Rev: AGGAACCAGGCACGAGCTT & \\
\hline \multirow[t]{2}{*}{ LITAF } & AY765397 & Fwd :CCCTTCTGAGGCATTTGGAA & \\
\hline & & Rev: CAGCCTGCAAATITTGTCTTCTT & \\
\hline \multirow[t]{2}{*}{ STAT-3 } & NM_001030931.1 & Fwd: TGGGTGGAGAAGGACATCA & \\
\hline & & Rev: CATGGGCAGGTCAATGGTAT & \\
\hline \multicolumn{4}{|l|}{ Duck } \\
\hline \multirow[t]{2}{*}{ Duck IL-6 } & AB191038 & Fwd :CCAAGGTGACGGAGGAAGAC & 5' (6FAM)TGTCTCCTGGCTGGCTTCGACGA 3' (TAMRA) \\
\hline & & Rev: TGGAGAGTTTCTTCAAGCATTTCTC & \\
\hline \multirow[t]{2}{*}{ Duck IL-8 } & AB236334.1 & Fwd :AGCCTGGTAAGGATGGGAAAC & 5' (6FAM)AGCTCCGGTGCCAGTGCATAAGCA 3' (TAMRA) \\
\hline & & Rev: GGGTGGATGAACTTCGAGTGA & \\
\hline \multirow[t]{2}{*}{ Duck IFN-a } & DQ861429 & Fwd :AACCAGCTTCAGCACCACATC & 5' (6FAM)TGCTTCCCAGCCGACGCC 3' (TAMRA) \\
\hline & & Rev: TGTGGTTCTGGAGGAAGTGTTG & \\
\hline
\end{tabular}


manufacturer's instructions. HPAI H5N1 virus challenge studies were performed with AHVLA committee ethical approval and in accordance with the UK 1986 Animal Scientific Procedure Act and AHVLA code of practice for performance of scientific studies using animals [License number 70/7062].

\section{STAT-3 over-expression and chemical inhibition}

Based on the high sequence identity of STAT-3 protein (97\%) between chicken and mouse, we used a mouse STAT-3 expression plasmid for this study. Primary chicken embryo cells in 6-well culture plates (Costar) were transiently transfected with constitutively active mouse STAT-3 expression plasmid [Stat3-C Flag pRc/CM $\mathrm{V}$, plasmid 8722, Addgene, USA] or empty pRc/CMV vector (Invitrogen) using TransIT-LT1 reagent (Mirus Bio, Cambridge, UK). At $80 \%$ cell confluence, transfection mixture containing $250 \mu \mathrm{L}$ Optimem, $2.5 \mu \mathrm{g}$ plasmid DNA and $7.5 \mu \mathrm{L}$ of TransIT reagent were added. Three days post-transfection, cells were infected with H5N1tyEng91 virus at MOI of 1.0.

Primary duck embryo cells were treated with STAT-3 inhibitor S3I-201 (Calbiochem, Merck, Nottingham, UK), a cell-permeable amidosalicylic acid compound that binds STAT3-SH2 domain and prevents STAT3 phosphorylation/activation, dimerization and DNA-binding, at a final concentration of $100 \mu \mathrm{M}$ [28] or vehicle (DMSO) control, one day before infection. Duck cells were pre-incubated with H5N1- tyEng91 virus at MOI of 1.0 for $2 \mathrm{~h}$ without S3I-201, after two hours the medium was removed, cells were rinsed with PBS and fresh medium with S3I-201 was replaced. At $24 \mathrm{hpi}$, cell lysates were harvested for protein and total RNA extractions. Western blotting was performed to detect phospho-STAT-3 (\#9131, Cell Signaling Technology, Hitchin, UK) and influenza nucleoprotein (NP) (AA5H, \#ab 20343, Abcam).

\section{Statistical analysis}

qRT-PCR data was subjected to statistical analysis by a randomization test with a pair-wise reallocation using relative expression analysis software tool $\left(\mathrm{REST}^{\odot}\right)$ [29].

\section{Results}

Comparable susceptibility to influenza virus infection and viral RNA accumulation in chicken and duck cells

Infection of primary chicken and duck lung cells with LPAI-H2N3, H5N1-tyEng91 or H5N1-tyTR05 at 1.0 multiplicity of infection (MOI) based on MDCK cell titration resulted in comparable levels of virus infection as determined by virus NP detection by immunocytochemistry at 6 hpi (Figure 1A to H). Influenza virus matrix gene expression at 24 hpi with LPAI-H2N3, H5N1-tyEng91 and H5N1-tyTR05 viruses was comparable in chicken and duck cells (Figure 1).

\section{More immune-related genes in chicken cells than duck cells were induced by influenza virus infection}

A DNA microarray based global gene expression approach with a chicken GeneChip array (Affymetrix) was used to identify differences in gene expression between chicken and duck primary lung cells in response to $24 \mathrm{~h}$ of infection with LPAI H2N3, H5N1-tyEng91 or H5N1-tyTR05 viruses. Microarray datasets are available on the gene expression omnibus (GEO) site under accession number GSE33389 [30]. "Probe mask file" generated with a duck genomic DNA hybridization intensity threshold of 200 provided the highest sensitivity for duck expression analysis on the chicken GeneChip platform (Figure 2). Probe masking resulted in a loss of 5639 transcripts out of the total 38535 transcripts represented in the original chicken GeneChip technology.

With one-way ANOVA and filtering at a $p<0.05$ from hybridization results of all 3 virus subtypes, 18783 out of 38535 transcripts $(48.74 \%)$ in chicken cells and, but only 7686 out of 32896 transcripts (23.36\%) in duck cells, were differentially regulated relative to corresponding controls.

The overlap among filtered genes based on fold change difference of virus infected (all three viruses) against mock infected samples provided a quantitative view of genes that were differentially expressed in chicken (Figure 3A) and duck (Figure $3 \mathrm{~B}$ ) cells following infection. Of the total number of differentially expressed genes, 12891 genes (33.45\%) in chicken cells and 3132 genes (9.52\%) in duck cells were common to all three viruses. Further comparative analysis showed that 546, 754 and 1361 genes were unique to LPAI H2N3, H5N1-tyEng91 and H5N1-tyTR05 infected chicken cells respectively (Figure $3 \mathrm{C}$ ). In duck cells, 645, 534 and 625 genes were unique to LPAI H2N3, H5N1-tyEng91 and H5N1-tyTR05 infection respectively (Figure 3D). Gene expression profiles were further analysed using the functional annotation tool in DAVID bioinformatics resources 6.7. Genes representing cytokines, chemokines, members of immunoglobulin super family, major histocompatibility complex (MHC), genes involved in $\mathrm{T}$ and $\mathrm{B}$ lymphocyte function and components of immune signalling pathways such as toll like receptor (TLR) pathway, and janus kinase (JAK) - signal transducer and activator of transcription (STAT) (JAK-STAT) pathway were classified as "immune" genes.

Several genes involved in key biological functions such as enzymes and transcription factors were down-regulated in HPAI H5N1virus infected chicken cells while most of these genes were either up-regulated or not affected in HPAI H5N1 virus infected duck cells (Table 2).

Many more immune-related genes were differentially regulated in chicken cells than in ducks cells in response to infection with the two HPAI H5N1 viruses. Of the 75 immune-related genes that were significantly up-regulated 


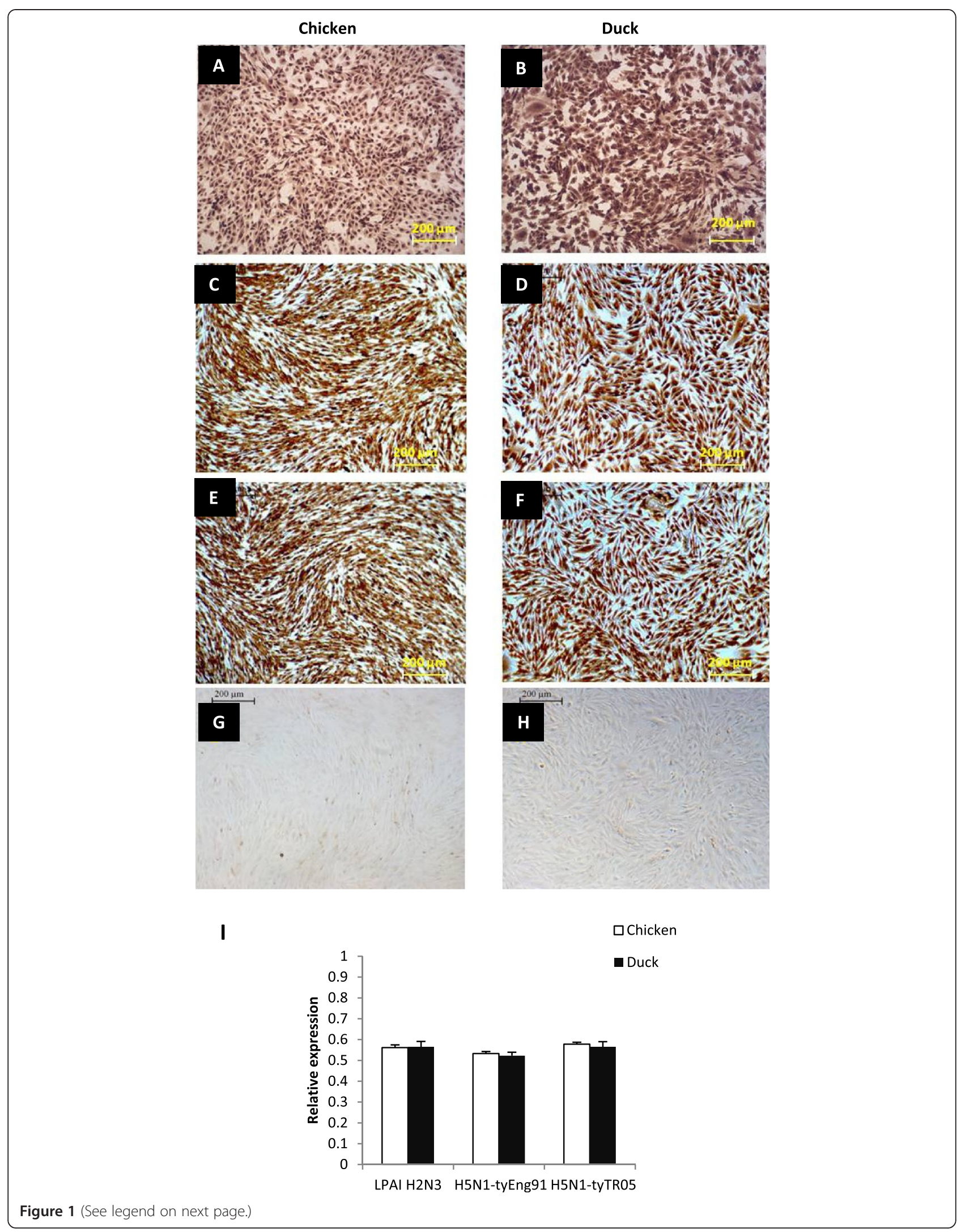


(See figure on previous page.)

Figure 1 Chicken and duck cells showed comparable susceptibility to influenza virus infection and viral RNA accumulation. At 6 hpi with LPAI H2N3, H5N1 tyEng91 or H5N1 tyTR05 virus infection at MOI 1.0, similar accumulation of influenza nucleoprotein (NP) was evident in chicken $(\mathbf{A}, \mathbf{C}, \mathbf{E})$ and duck (B,D,F) cells as detected by immunocytochemistry. Mock-infected chicken $\mathbf{( G )}$ and duck (H) cells show no staining. Comparable accumulation of viral matrix gene RNA between chicken and duck cells at 24 hpi at $1.0 \mathrm{MOI}$ with LPAI H2N3, H5N1-tyEng91 or H5N1 tyTR05 viruses (I). Data were derived from biological replicates of 3 total RNA samples and the data points are mean relative expression values normalized to 18SrRNA expression.

in HPAI H5N1-tyEng91 virus infected chicken cells (fold change $\geq 1.3$ and $p<0.05)$, expression of 63 genes $(84 \%)$ was not significantly affected $(p>0.05)$ and 12 genes $(16 \%)$ were significantly down-regulated $(p<0.05)$ in corresponding duck cells. Full list of immune related genes that were differentially regulated between $\mathrm{H} 5 \mathrm{~N} 1$ virus infected chicken and duck cells is provided as an additional file (see Additional file 2). A similar difference in immune related gene expression was also observed between chicken and duck cells at 24 h H5N1-tyTR05 virus infection (see Additional file 2). However, some of these immune genes were down-regulated in chicken cells infected with LPAI H2N3 and the genes that were up-regulated showed a lower fold increase than those in the HPAI infected chicken cells (see Additional file 2).

\section{Pro-inflammatory genes were up-regulated in infected chickens (lung cells and in vivo) but not in ducks}

Pro-inflammatory cytokine genes, interleukin (IL)- 6, IL-8 (CXCLi1) and $I L-10$, were highly up-regulated in both HPAI H5N1 virus infected chicken cells; in contrast, $I L-8$ expression was unchanged, and $I L-6$ and $I L-10$ were down regulated in infected duck cells with the same viruses (Table 3). Expression of $I L-18$ was up-regulated in duck cells but was down-regulated in chicken cells following infection with H5N1-tyEng91 or H5N1-tyTR05 viruses (Table 3).

Messenger RNA expression levels of LITAF, IL-6 and $I L-8$ were significantly up-regulated $(p<0.05)$ in chicken cells infected with LPAI-H2N3 (Figure 4A), H5N1-tyEng91 (Figure 4C) or H5N1-tyTR05 viruses (Figure 4E). However, higher fold increase in the expression was observed in HPAI viral infections (Figures $4 \mathrm{C}$ and $\mathrm{E}$ ) compared with LPAI virus infection (Figure 4A) in chicken cells. In contrast, the three pro-inflammatory genes were either significantly down-regulated $(p<0.05)$ or not significantly altered $(p>0.05)$ in duck cells infected with LPAI H2N3 (Figure 4B), H5N1-tyEng91 (Figure 4D) or H5N1-tyTR05 viruses (Figure $4 \mathrm{~F}$ ).

Significant up-regulation $(p<0.05)$ of LITAF (Figure 5A), $I L-6$ (Figure 5B) and $I L-8$ (Figure $5 \mathrm{C}$ ) was also detected in lung and spleen tissues from three-week-old chickens at $24 \mathrm{~h}$ of infection with H5N1-tyTR05 or H5N1-tyEng91 HPAI viruses (data not shown), along with abundance of

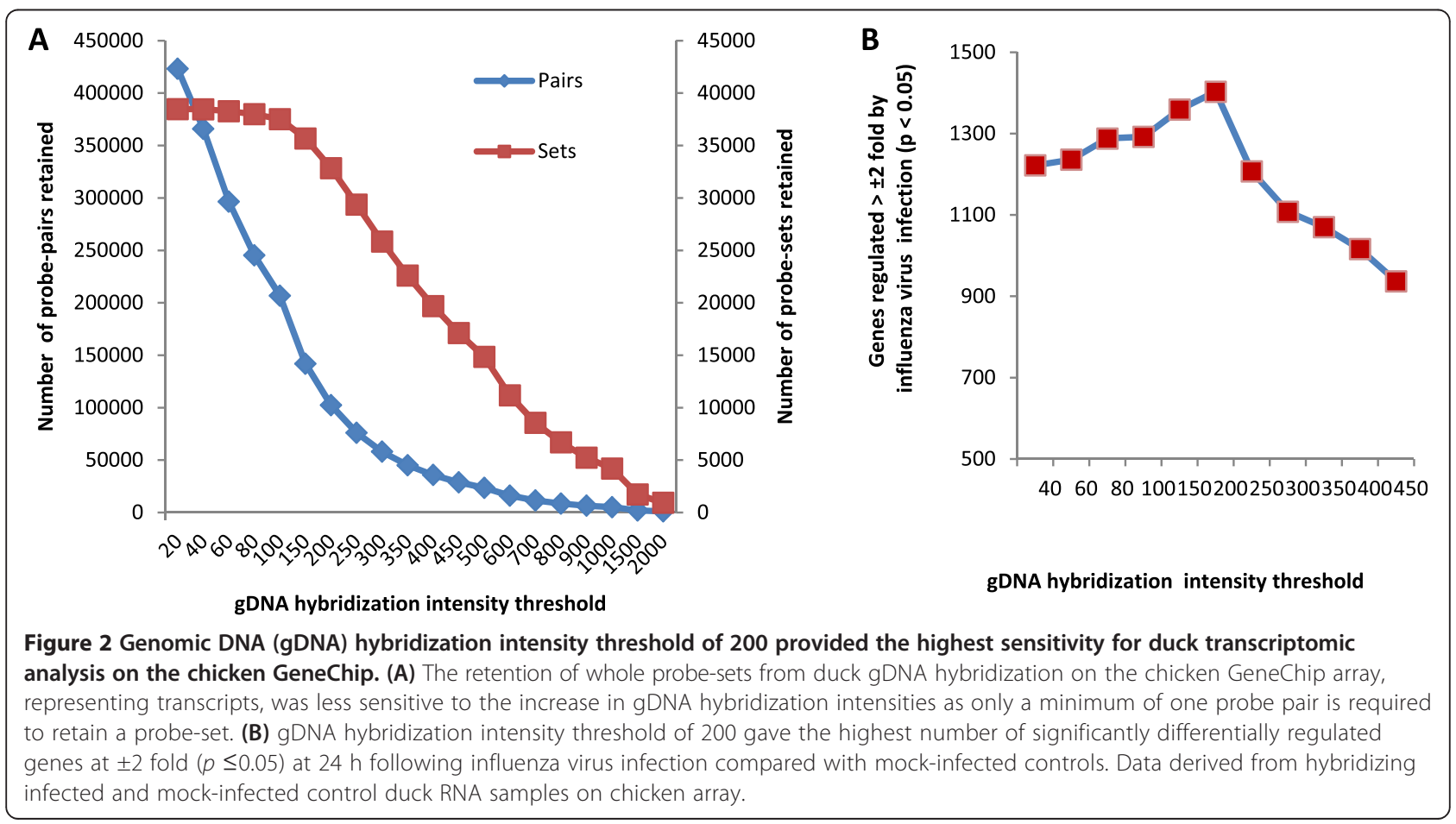




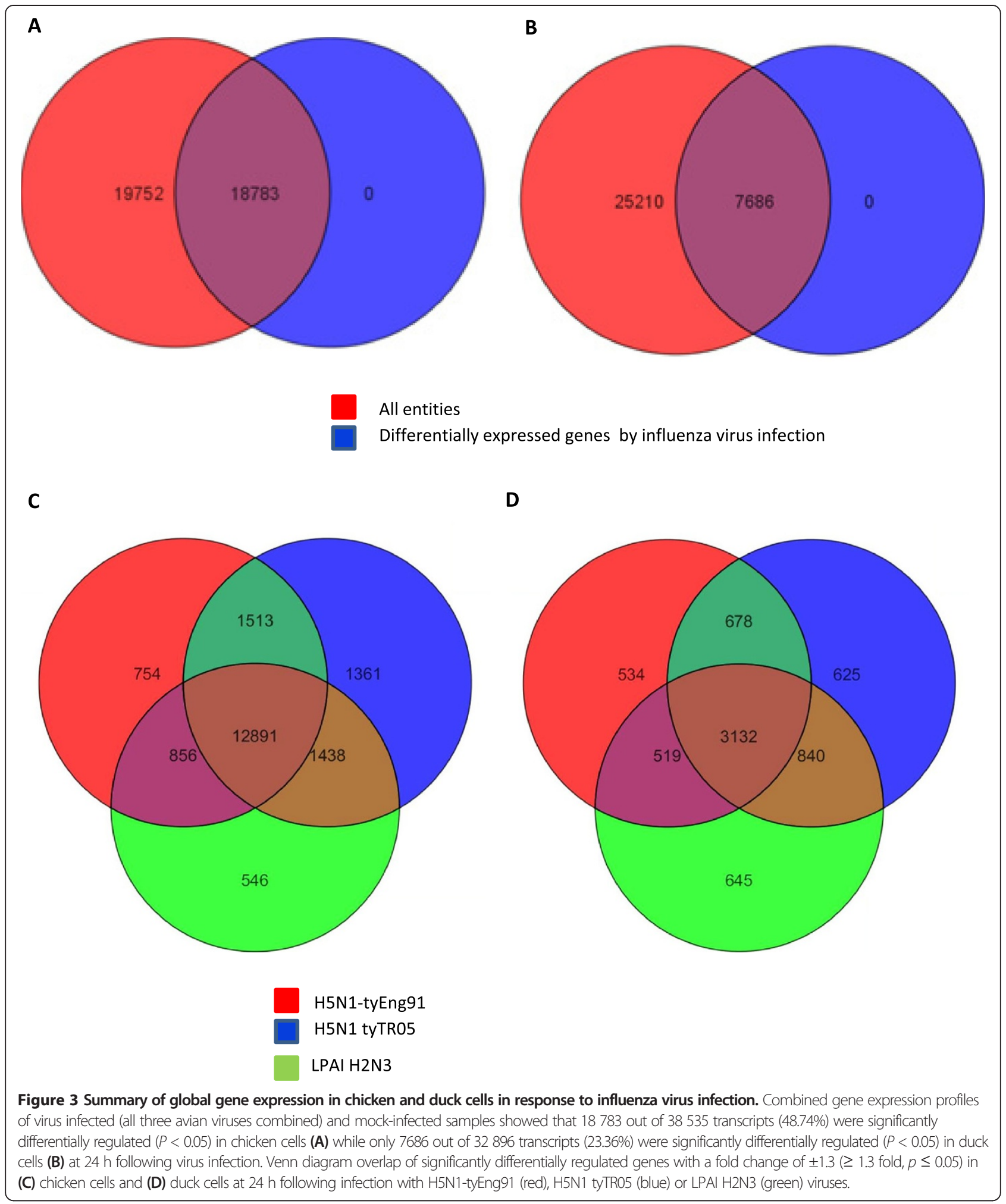

virus matrix gene expression (Figure 5D). In lung and spleen tissues of 3-week-old Pekin ducks taken at $24 \mathrm{~h}$ of infection with H5N1-tyTR05 virus, despite the detection of virus matrix gene expression (Figure 5H), LITAF
(Figure 5E) expression was significantly down-regulated $(p<0.05)$; $I L-6$ (Figure 5F) and $I L-8$ (Figure 5G) expression was not significantly affected $(p>0.05)$. In summary, similar elevated pro-inflammatory response in chickens but 
Table 2 Differential expression of genes involved in key biological functions between HPAIV infected chicken and duck cells (detected by microarray)

\begin{tabular}{|c|c|c|c|c|c|c|c|c|c|c|}
\hline \multirow{3}{*}{$\begin{array}{l}\text { Gene } \\
\text { symbol }\end{array}$} & \multirow[t]{3}{*}{ Gene name } & \multirow{3}{*}{$\begin{array}{l}\text { Entrez } \\
\text { Gene ID }\end{array}$} & \multicolumn{4}{|c|}{ Chicken cells } & \multicolumn{4}{|c|}{ Duck cells } \\
\hline & & & \multicolumn{2}{|c|}{ H5N1-tyEng91 } & \multicolumn{2}{|c|}{ H5N1-tyTR05 } & \multicolumn{2}{|c|}{ H5N1-tyEng91 } & \multicolumn{2}{|c|}{ H5N1-tyTR05 } \\
\hline & & & $\begin{array}{l}\text { Fold } \\
\text { change }\end{array}$ & Regulation & $\begin{array}{l}\text { Fold } \\
\text { change }\end{array}$ & Regulation & $\begin{array}{l}\text { Fold } \\
\text { change }\end{array}$ & Regulation & $\begin{array}{l}\text { Fold } \\
\text { change }\end{array}$ & Regulation \\
\hline \multicolumn{11}{|c|}{ Signal transduction } \\
\hline PRKAR2A & $\begin{array}{l}\text { Protein kinase, CAMP-dependent, } \\
\text { regulatory, type II, alpha }\end{array}$ & 416062 & 2.27 & up & 4.59 & down & 3.96 & down & 5.86 & down \\
\hline IPO7 & Importin 7 & 423046 & - & unchanged & 2.21 & down & 4.83 & up & 2.99 & down \\
\hline \multicolumn{11}{|c|}{ GTPase inhibitor activity } \\
\hline GPS1 & G protein pathway suppressor 1 & 417382 & 2.86 & down & 3.01 & down & 2.21 & up & 3.2 & up \\
\hline \multicolumn{11}{|c|}{ Lipid metabolism, production of ROS } \\
\hline ACOX1 & $\begin{array}{l}\text { Acyl-Coenzyme A oxidase 1, } \\
\text { palmitoyl }\end{array}$ & 417366 & 4.33 & down & 2.88 & down & - & unchanged & 3.24 & up \\
\hline \multicolumn{11}{|l|}{ Enzymes } \\
\hline B4GALNT3 & $\begin{array}{l}\text { Beta-1,4-N-acetyl-galactosaminyl } \\
\text { transferase } 3\end{array}$ & 418150 & 2.07 & down & 1.33 & up & 2.58 & up & 2.08 & up \\
\hline DNPEP & Aspartyl aminopeptidase & 424200 & 2.38 & up & 1.3 & up & - & unchanged & 1.44 & down \\
\hline \multicolumn{11}{|c|}{ Catalytic activity (vit B6 metabolism) } \\
\hline PSAT1 & Phosphoserine aminotransferase 1 & 427263 & 4.38 & down & 3.9 & down & 11.44 & up & 11.69 & up \\
\hline \multicolumn{11}{|c|}{ Transcription factor } \\
\hline RREB1 & $\begin{array}{l}\text { Ras responsive element binding } \\
\text { protein } 1\end{array}$ & 395920 & 3.41 & down & 2.26 & down & 2.73 & up & 7.31 & up \\
\hline \multicolumn{11}{|c|}{ Isoleucyl-tRNA aminoacylation } \\
\hline IARS2 & $\begin{array}{l}\text { Isoleucyl-tRNA synthetase } 2 \text {, } \\
\text { mitochondrial }\end{array}$ & 421346 & 17.58 & down & 22.92 & down & 14.52 & up & 38.82 & up \\
\hline \multicolumn{11}{|c|}{ Peptidolysis, IL-4 biosynthesis } \\
\hline MMP28 & Matrix metallopeptidase 28 & 417523 & 2.66 & down & 1.93 & down & 3.31 & up & 10.38 & up \\
\hline
\end{tabular}

subdued pro-inflammatory response in ducks was observed in vitro and in vivo.

\section{Comparable type I Interferon response between influenza} virus infected chickens and ducks

Interferon alpha $(I F N-\alpha)$ expression was up-regulated in chicken (Figure 6A) and duck (Figure 6B) cells at $24 \mathrm{~h}$ of infection with LPAI-H2N3, H5N1-tyEng91 or H5N1tyTR05 virus. Similar significant up-regulation of IFN- $\alpha$ expression was observed in the lung and spleen tissues of chickens at $24 \mathrm{~h}$ post-challenge with $\mathrm{H} 5 \mathrm{~N} 1$-tyTR05 (Figure 7B) or H5N1-tyEng91 HPAI viruses (data not shown). Up-regulation of $I F N-\alpha$ was also found in the lung and spleen tissues of ducks $24 \mathrm{~h}$ post-challenge with H5N1-tyTR05 HPAI virus (Figure 7D).

\section{Differential regulation of key components of JAK-STAT} pathway between influenza virus infected chicken and duck cells

Contrasting transcriptional regulation of JAK-STAT pathway between infected chicken and duck cells was observed by microarray (Table 3). Following $24 \mathrm{~h}$ of infection with H5N1-tyEng91 or H5N1-tyTR05 virus, members of JAKSTAT signalling pathway (JAK1, IFN- $\alpha$ receptor 1 [IFNAR1], STAT-3 and protein inhibitor of activated STAT 2 [PIAS2]) were down-regulated in chicken cells. In duck cells, expression of IFNAR1, PIAS2 and STAT-3 was up-regulated by LPAI H2N3 or H5N1-tyEng91 virus infection. Duck JAK1 gene was removed during the probe masking procedure and hence its expression was not determined. Notably, in duck cells infected with H5N1-tyTR05 virus, PIAS2 expression was down-regulated, STAT3 was unchanged and IFNAR1 was up-regulated.

STAT-3 mRNA expression was validated in chicken and duck cells by qRT-PCR using the same total RNA samples that were used for microarray analysis. While STAT-3 expression was not significantly affected $(P>0.05)$ by LPAI H2N3 virus infection, its expression was significantly reduced to half as much $(P<0.05)$ by H5N1tyEng91 or H5N1-tyTR05 virus in infected chicken cells (Figure 6C). In duck cells, by contrast, STAT-3 expression was significantly up-regulated $(P<0.05)$ by LPAI H2N3 
Table 3 Differential expression of key immune related genes between HPAIV infected chicken and duck cells (detected by microarray)

\begin{tabular}{|c|c|c|c|c|c|c|c|c|c|c|}
\hline \multirow{3}{*}{$\begin{array}{l}\text { Gene } \\
\text { symbol }\end{array}$} & \multirow[t]{3}{*}{ Gene name } & \multirow{3}{*}{$\begin{array}{l}\text { Entrez } \\
\text { Gene ID }\end{array}$} & \multicolumn{4}{|c|}{ Chicken cells } & \multicolumn{4}{|c|}{ Duck cells } \\
\hline & & & \multicolumn{2}{|c|}{ H5N1-tyEng91 } & \multicolumn{2}{|c|}{ H5N1-tyTR05 } & \multicolumn{2}{|c|}{ H5N1-tyEng91 } & \multicolumn{2}{|c|}{ H5N1-tyTR05 } \\
\hline & & & $\begin{array}{l}\text { Fold } \\
\text { change }\end{array}$ & Regulation & $\begin{array}{l}\text { Fold } \\
\text { change }\end{array}$ & Regulation & $\begin{array}{l}\text { Fold } \\
\text { change }\end{array}$ & Regulation & $\begin{array}{l}\text { Fold } \\
\text { change }\end{array}$ & Regulation \\
\hline \multicolumn{11}{|c|}{ JAK-STAT Pathway } \\
\hline STAT3 & $\begin{array}{l}\text { signal transducer and activator } \\
\text { of transcription } 3\end{array}$ & 420027 & 2.33 & down & 2.72 & down & 1.39 & up & - & unchanged \\
\hline JAK1 & $\begin{array}{l}\text { Janus kinase } 1 \text { (a protein } \\
\text { tyrosine kinase) }\end{array}$ & 554219 & 2.79 & down & 3.21 & down & - & Removed* & - & Removed* \\
\hline IFNAR1 & $\begin{array}{l}\text { Interferon (alpha, beta and } \\
\text { omega) receptor } 1\end{array}$ & 395665 & 8.02 & down & 16.65 & down & 13.91 & up & 1.37 & up \\
\hline PIAS2 & $\begin{array}{l}\text { Protein inhibitor of activated } \\
\text { STAT, } 2\end{array}$ & 416383 & 5.05 & down & 3.86 & down & 1.62 & up & 3.7 & down \\
\hline \multicolumn{11}{|c|}{ Cytokines and Chemokines } \\
\hline $\begin{array}{l}\text { IL8/ CXCLi1 } \\
\text { (K60) }\end{array}$ & interleukin 8 & 395872 & 232.8 & up & 2.96 & up & - & unchanged & - & unchanged \\
\hline IL6 & $\begin{array}{l}\text { interleukin } 6 \text { (interferon, } \\
\text { beta 2) }\end{array}$ & 395337 & 131.08 & up & 10.66 & up & 2.92 & down & - & unchanged \\
\hline IL10 & interleukin 10 & 428264 & 1.39 & up & 1.6 & up & 1.39 & down & - & unchanged \\
\hline IL18 & $\begin{array}{l}\text { interleukin } 18 \text { (interferon- } \\
\text { gamma-inducing factor) }\end{array}$ & 395312 & 4.7 & down & 4.14 & down & 3.02 & up & 2.4 & up \\
\hline
\end{tabular}

*Transcript removed during probe masking.

and H5N1-tyEng91 virus infection; STAT-3 expression was not significantly affected $(P>0.05)$ by H5N1-tyTR05 virus infection (Figure 6D). Similarly, STAT-3 mRNA expression was down-regulated in the lung and spleen tissues of chickens challenged with H5N1-tyTR05 virus (Figure 7A) or H5N1-tyEng91 virus (data not shown). STAT-3 mRNA expression in the lung and spleen tissues was not significantly different $(p>0.05)$ in ducks challenged with H5N1-tyTR05 HPAI virus compared with controls (Figure 7C). In summary HPAI H5N1 virus infection resulted in down-regulation of key members of the JAK-STAT signalling pathway in chicken cells but not duck cells.

\section{STAT-3 appears to negatively regulate virus-induced} pro-inflammatory response and promote virus replication in chicken and duck cells

We examined the phospho-STAT-3 protein expression in chicken and duck cells using a monoclonal antibody that is specific to pSTAT-3 at tyrosine-705. PhosphoSTAT-3 protein in primary duck cells was expressed constitutively and remained strongly expressed at $24 \mathrm{~h}$ of infection with H5N1-tyEng91 or H5N1-tyTR05 virus (Figure 6E). In primary chicken cells, by contrast, phosphoSTAT-3 was weakly expressed before infection and undetectable at 24 hpi with H5N1-tyEng91 or H5N1-tyTR05 virus (Figure 6E).

To demonstrate a possible functional role of phosphoSTAT-3 in mediating host pro-inflammatory response during influenza virus infection, primary chicken cells were transiently transfected with a phospho-STAT-3 expression plasmid, and duck cells were treated with STAT3 Inhibitor VI (S3I-201) prior to challenge with the H5N1-tyEng91 virus. High expression of p-STAT-3 protein in chicken cells over-expressing pSTAT-3 and reduced p-STAT-3 expression in duck cells treated with S3I-201 at $24 \mathrm{~h}$ following virus infection was detected by western blotting (Figure 8A).

Chicken cells transiently transfected with phosphoSTAT-3 showed a significant $(p<0.05)$ reduction in LITAF, IL-6 and IL-8 mRNA expression following $24 \mathrm{~h}$ of H5N1-tyEng91 virus infection (Figure 8B). In duck cells treated with S3I-201, a significant $(p<0.05)$ increase of LITAF, IL-6 and IL-8 mRNA expression was observed at $24 \mathrm{~h}$ post $\mathrm{H} 5 \mathrm{~N} 1$-tyEng91 virus infection (Figure $8 \mathrm{C}$ ). STAT-3 over expression in chicken cells or inhibition in duck cells had no significant $(p>0.05)$ effect on the expression of IFN- $\alpha$ expression following H5N1-tyEng91 virus infection. Chicken cells over- expressing phospho STAT-3 showed marginal increase in viral nucleo-protein (NP) expression (Figure 8A), significantly increased $(p<0.05)$ matrix gene mRNA expression (Figure 8D) and infectious virus release in culture supernatant (Figure $8 \mathrm{E}$ ) at $24 \mathrm{~h}$ post H5N1-tyEng91 virus infection. STAT-3 inhibition had no effect on virus NP (Figure 8A), matrix gene expression $(p>0.05)$ (Figure $8 \mathrm{D})$ or infectious virus production at $24 \mathrm{~h}$ post H5N1-tyEng91 virus infection in duck cells. In summary STAT-3 over-expression in chicken cells 


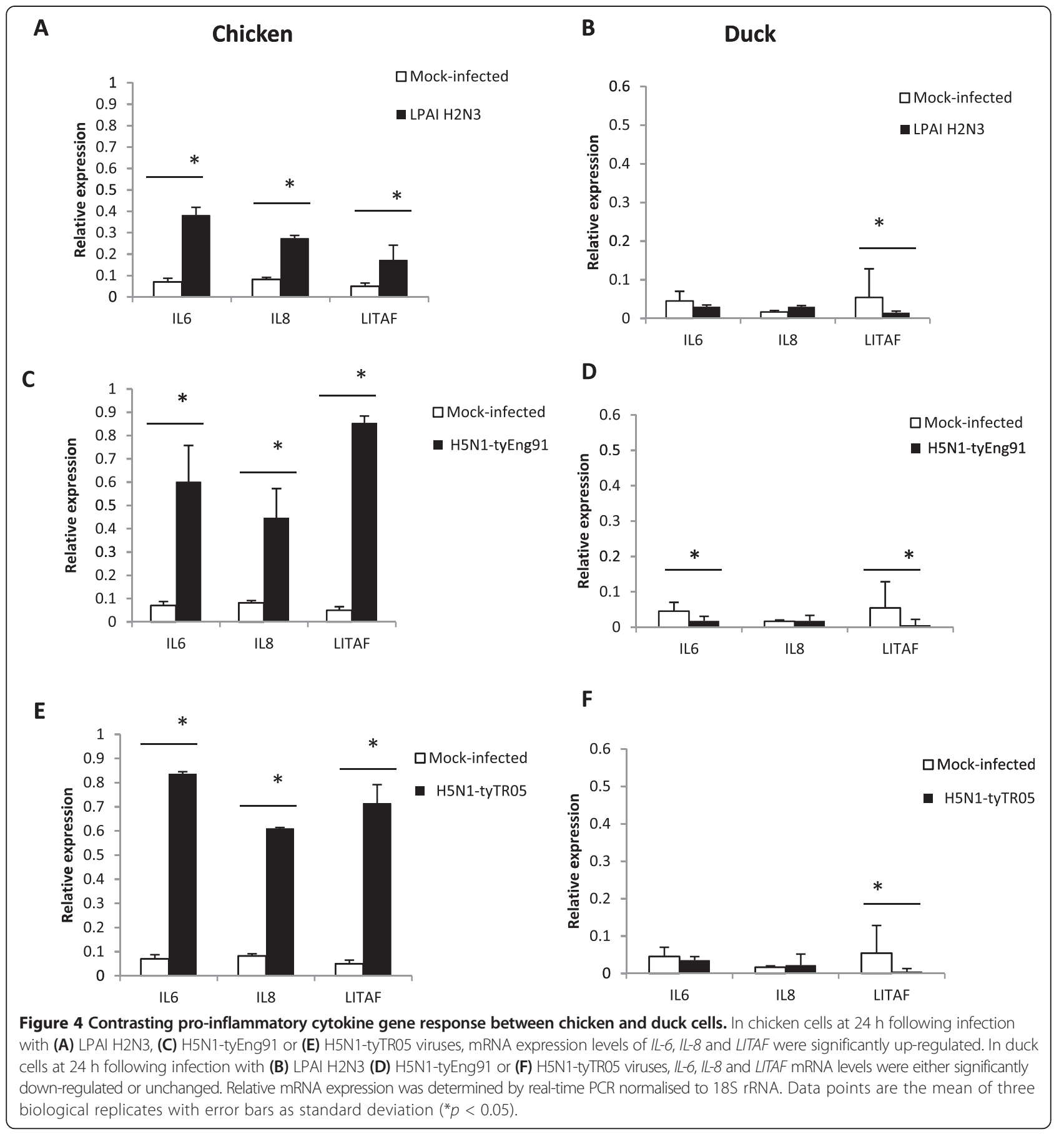

resulted in significant reduction whereas chemical inhibition of STAT-3 in duck cells resulted in significant increase in the proinflammatory gene response to $\mathrm{H} 5 \mathrm{~N} 1$ virus infection.

\section{Discussion}

Microarray global gene expression analysis is a useful tool to gain important insights into the effects of influenza virus infection on host gene expression that could contribute to influenza pathogenesis [31]. As commercial high density microarray platforms are not yet available for many avian species, cross species hybridization using chicken oligonucleotide microarray is a useful tool to investigate gene expression in a range of avian species [32]. In this study, we successfully demonstrated that the Chicken GeneChip array could be used for the analysis of duck transcriptome as in the previous studies with woodchuck RNA on human microarrays [33] and pig 
RNA on human nylon microarrays [31]. However, direct high-throughput sequencing approach (RNA-Seq) is increasingly becoming popular. RNA-seq approach provides considerable advantages for examining transcriptome fine structure such as detection of allele-specific expression and splice junctions [34]. However, microarrays remain useful and accurate tools for measuring gene expression levels especially for cross-species studies where the full genome sequence and/or annotation are not available.

We found that influenza virus infection caused differential regulation of a greater number of genes involved in key biological functions in chicken cells compared with that in duck cells. Such changes in vivo could well account for the alterations in the function of infected cells and the pathogenesis of influenza virus in chicken. The relatively fewer changes in differential gene expression in infected duck cells suggest that cellular function was affected to a lesser degree than in chickens. $\mathrm{HPAI}$ viruses like $\mathrm{H} 5 \mathrm{~N} 1$ cause severe clinical disease in chickens and cause differential regulation of many genes involved in protein metabolism, translation, transcription, host defence/immune response, ubiquitination and the cell cycle [35].

Lethal influenza virus infections have been previously shown to cause an aberrant host innate immune response $[18,36]$. In this study we showed that HPAI virus infection caused an elevated immune gene response in chicken cells but not in duck cells. We previously showed that a moderated pro-inflammatory response plays an important role in mediating innate host resistance of pigs to $\mathrm{H} 5 \mathrm{~N} 1$ virus infection [17]. The present study found an elevated pro-inflammatory gene 


\section{Chicken}

A

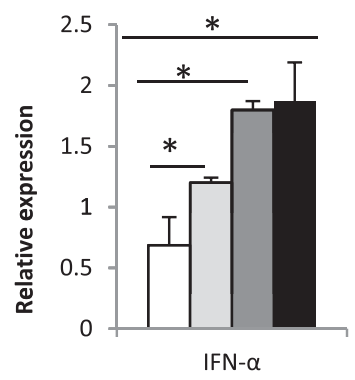

C

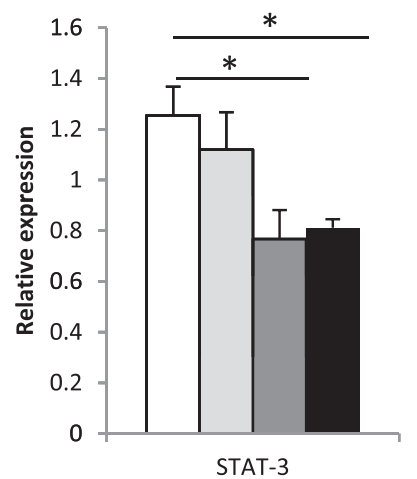

Duck

B

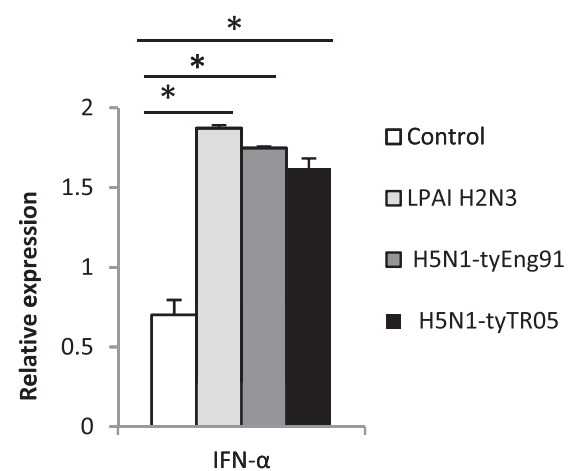

D

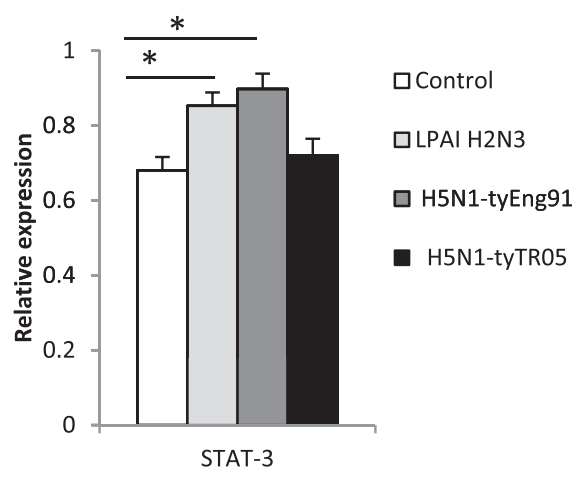

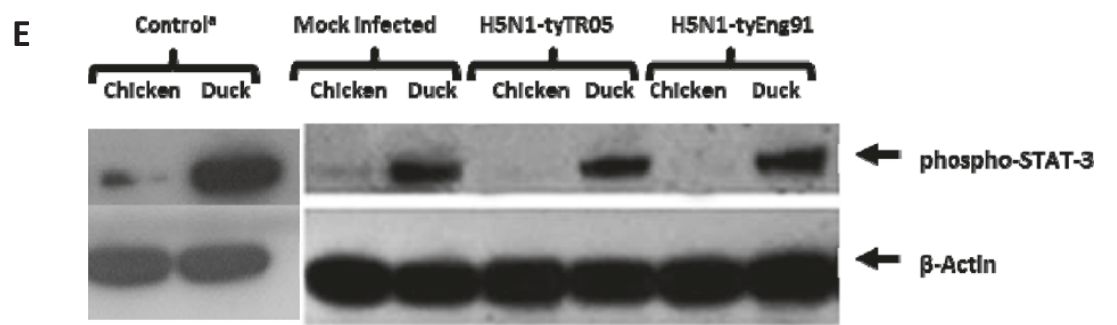

Figure 6 Infected chicken and duck cells showed differential regulation of STAT-3. IFN- $a$ expression was significantly up-regulated in chicken (A) and duck (B) cells at $24 \mathrm{~h}$ following infection with LPAI-H2N3, H5N1-tyEng91 or H5N1-tyTR05 viruses. (C) While STAT-3 expression in chicken cells was not significantly affected by LPAI-H2N3 virus infection it was significantly down-regulated in H5N1-tyEng91 and H5N1-tyTR05 virus infections. (D) In contrast STAT-3 expression in duck cells was significantly up-regulated by LPAI-H2N3 or H5N1-tyEng91 viruses but was not affected by H5N1-tyTR05 virus infection. Relative mRNA expression was determined by real-time PCR normalised to 18S rRNA. Data points are the mean of three biological replicates with error bars as standard deviation $\left({ }^{*} p<0.05\right)$. (E) Strong constitutive phospho-STAT-3 protein expression was detected in duck cells which was unaffected at $24 \mathrm{~h}$ following infection with H5N1-tyEng91 and H5N1-tyTR05 viruses. In chicken mock-infected cells, phospho-STAT3 protein expression was scarcely detectable and remained absent at $24 \mathrm{~h}$ following virus infection. ㄹonger (5 min) exposure showing pSTAT-3 in chicken cells.

response in infected chickens and an attenuated inflammatory response in ducks following $24 \mathrm{~h}$ of infection with HPAI virus. The unusual severity of clinical human cases of H5N1 HPAI virus infection has been suggested to be linked to the hyperacute dysregulation of pro-inflammatory cytokines often referred as cytokine storm [14,15,37]. Tumour Necrosis Factor alpha $(T N F-\alpha)$ plays a major role in the development of clinical signs like fever and contributes to the lung lesions in humans [38] and pigs [39] during influenza virus infections. Due to absence of a "conventional" TNF- $\alpha$ gene in birds, expression of a lipopolysaccharide induced TNF alpha factor (LITAF) was analyzed in this study. LITAF gene has been previously shown to be very highly up regulated along with other pro-inflammatory cytokines following experimental inoculation of E.coli and Salmonella endotoxins [40] and LPAIV [41,42]. It is likely that the downstream pathways activated by LITAF might have a similar function as TNF- $\alpha$ in other species. We found an increased expression of LITAF in chickens and a 
down-regulated LITAF expression in ducks infected with H5N1-tyEng91 or H5N1-tyTR05 viruses. Similar increased expression of other pro-inflammatory cytokines $I L-6$ and $I L-8$ was observed in chickens, but not in ducks, infected with HPAIV [43].

However, pro-inflammatory response in ducks to different H5N1 virus strains could be inherently different. For example, a number of innate immune genes are up-regulated in the lungs of duck infected with a HPAI H5N1 virus (A/duck/Hubei/49/05), a LPAI H5N1 virus (A/goose/ Hubei/65/05) [44] and a HPAI H5N1 virus (A/Vietnam/ 1203/04) [45]. In theory, the lack of such robust innate immune activation in ducks in vitro and in vivo following H5N1-tyTR05 virus could be due to inability of virus replication, or inherent differences in ducks response to different viral strains. However, H5N1-tyTR05 virus replicates to high titres in ducks with detectable viral shedding in oropharyngeal and cloacal swabs [12] and in vitro as shown by NP staining and M gene quantification. Hence, it is likely that there are inherent differences in the response of ducks to different subtypes of HPAI H5N1 viruses.

A previous study suggested that relative susceptibility of chickens to influenza virus, compared with ducks, could be due to the absence of RIG-I in chickens, a cytoplasmic RNA sensor that plays a key role in IFN mediated anti-viral responses [46]. However, a reduced IFN- $\beta$ response in chicken cells in comparison with duck cells does not always seem to be a consistent observation in all influenza virus infections. Chicken peripheral blood mononuclear cells (PBMC) showed up-regulation of IFN$\beta$ while the levels of IFN- $\beta$ are unaffected in duck PBMCs infected with a low pathogenic LPAI H11N9 influenza virus [47]. Type I interferon (IFN) response to AIV infection in chicken cells is mediated through melanoma differentiation-associated protein 5 (MDA-5) which chicken use to sense IAV infection [48]. Role of host IFN- $\alpha / \beta$ response in regulating virus replication is complex. In mice IFN- $\alpha / \beta$ causes either suppression or enhancement of hepatitis B virus (HBV) replication depending on the viral load [49]. Furthermore, a high host interferon IFN response to H5N1 HPAI virus may not, by itself, be sufficient to prevent a severe disease outcome. Conversely, host immune responses to HPAI H5N1 virus infection may contribute to disease pathogenesis. In human cases of HPAI H5N1 virus infection, higher levels of cytokines and chemokines were found in the blood of patients who died than those who survived [50-52].

The present study did not find any difference in IFN- $\alpha$ expression in chickens and ducks following H5N1 HPAI virus infection both in vitro and in vivo, raising a possibility that an IFN- $\alpha$ response by itself may not be sufficient to protect the host against virulent influenza virus infection. A study found strong up-regulation of IFN- $\gamma$ mRNA in the lung and bursa of ducks but not chicken following infection with a LPAI H7N1 virus [53]. It is possible that IFN- $\gamma$ rather than IFN- $\alpha$ or $\beta$ could be important in protection against virulent influenza infection in avian hosts which warrants further studies.

In summary, we showed that host pro-inflammatory responses could be a key contributing factor to the pathogenesis of H5N1 influenza viruses and that the fatal outcome of H5N1 HPAI virus infection in chickens could be mediated by hyper-acute dysregulation of pro-inflammatory cytokines or the cytokine storm similar to human H5N1 HPAI virus infections. Furthermore, ducks showed attenuated proinflammation following infection with both the H5N1 viruses used in this study. However, to evaluate virus subtype specific differences, further comparative studies are required to assess the differences in cytokine response between ducks infected with different H5N1 virus isolates.

We found that $I L-18$ was up-regulated in duck cells, but was down regulated in chicken cells infected with HPAIV. IL-18 is involved in the control of influenza virus replication in the lungs of infected mice, especially at an early stage of infection, through activation of the innate immune mechanisms such as IFN and natural killer (NK) cells [54] and improves the early defence system by augmenting NK cell-mediated cytotoxicity. IL-18 plays a critical role in the development of protective immunity against various intracellular pathogens including Mycobacterium tuberculosis, Yersinia enterocolitica, Cryptococcus neoformans and herpes simplex virus [55-58]. Recent studies demonstrated that recombinant vaccines simultaneously expressing influenza antigens along with IL-18 significantly enhance the protective efficacy of influenza vaccines in chicken [9]. A study also found that LPAI but not HPAI infection is associated with enhanced NK cell response in lungs of chicken [59], suggesting a crucial role of NK cell response in influenza virus pathogenesis. This evidence warrants further functional studies to investigate the mechanisms underlying the protective role of IL-18 and NK cell response during influenza virus infections in chicken.

The JAK-STAT signalling pathway is activated by the type I (IFN- $\alpha$ and IFN- $\beta$ ) and type II (IFN- $\gamma$ ) interferons [60] and is critical for a successful IFN- $\alpha$ antiviral response against virus infections [61]. This study found that key genes in JAK-STAT signalling pathway were down-regulated in chicken cells but were either upregulated or unchanged in duck cells at $24 \mathrm{~h}$ following HPAIV infection. STAT-3, a key constituent of this pathway plays a critical role in the IFN signalling pathways and is required for a robust IFN-induced antiviral response [62].

STAT family proteins are activated by phosphorylation by JAKs on a single tyrosine in the $\mathrm{C}$ - terminus at position 705 that enables their homo- or hetero-dimerization. Dimerized STAT proteins subsequently migrate to the nucleus and stimulate transcription [63]. Hence 


\section{Chicken}

A

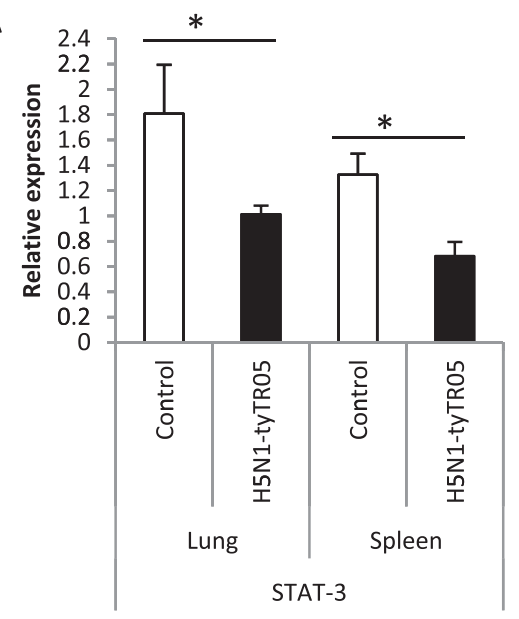

B

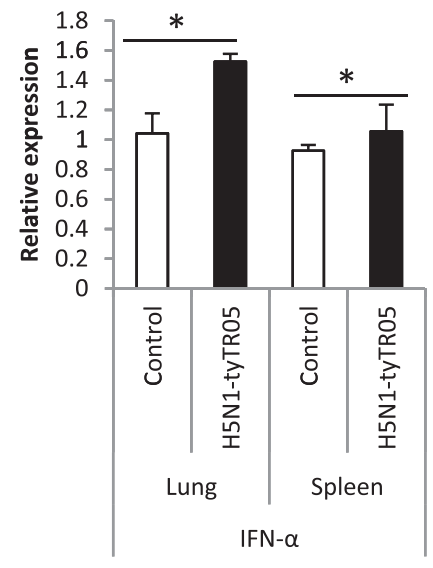

Duck

C

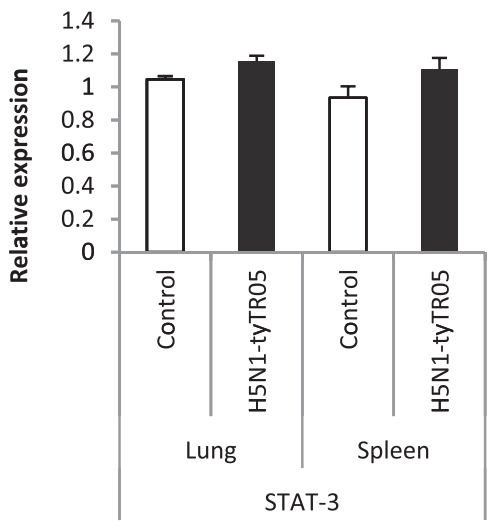

\section{D}

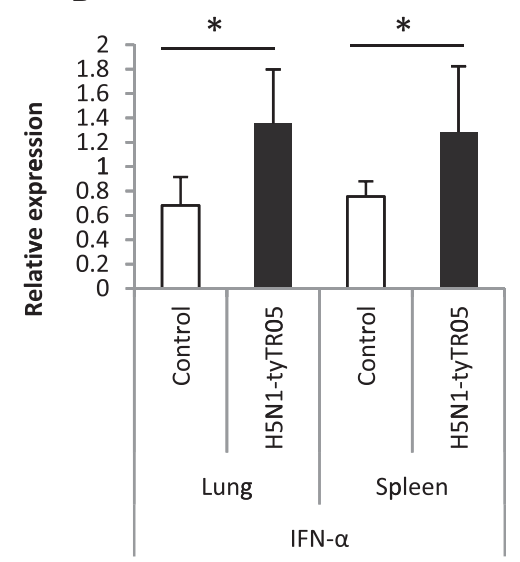

Figure 7 Differential STAT-3 regulation between H5N1 virus-infected chickens and ducks. In the lungs and spleens of 3-weeks-old chickens at $24 \mathrm{~h}$ following infection with H5N1-tyTR05 viruses, (A) expression of STAT-3 was significantly down-regulated whereas (B) IFN-a was significantly up-regulated. In the lung and spleen tissues from 4- weeks- old ducks at $24 \mathrm{~h}$ following infection with H5N1-tyTR05 virus, (C) STAT-3 expression was unaffected and (D) IFN-a expression was significantly up-regulated. Relative mRNA expression was determined by real-time PCR normalised to 185 rRNA. Data points are the mean of three biological replicates with error bars as standard deviation $\left({ }^{*} p<0.05\right)$.

phosphorylation of STAT-3 at tyrosine- 705 is a key indicator of its DNA binding ability and activity as a transcription factor. We found that duck cells had a high basal expression of pSTAT-3 (Tyr705) compared with chicken cells. pSTAT-3 (Tyr705) protein expression was undetectable in chicken cells $24 \mathrm{~h}$ after infection with HPAI H5N1 virus while it was unaffected during infection of duck cells. We could not verify STAT-3 protein expression in-vivo due to unavailability of protein samples from HPAI infected chickens and ducks. The transcriptional downregulation of STAT-3 with corresponding lack of pSTAT-3 protein expression in chicken cells suggests that $\mathrm{H} 5 \mathrm{~N} 1$ HPAI virus infection inhibits STAT-3 mediated gene transcription and/or activation. An important function of STAT-3 is its antagonistic effect on the inflammatory response. Activation of the STAT-3 signaling pathway promotes a strong anti-inflammatory response thereby blocking the inflammatory cytokine response [64]. Hence, it is likely that the excessive pro-inflammatory response in H5N1 HPAI virus infected chickens could be mediated through the inhibition of STAT-3 and a functional STAT3 corresponds to an attenuated pro-inflammation in H5N1 virus infected ducks. In addition, $I L-18$ stimulation results in enhanced tyrosine phosphorylation of STAT-3 [65]. In the present study $I L-18$ activation correlated with increased STAT-3 phophorylation in duck cells while 
A

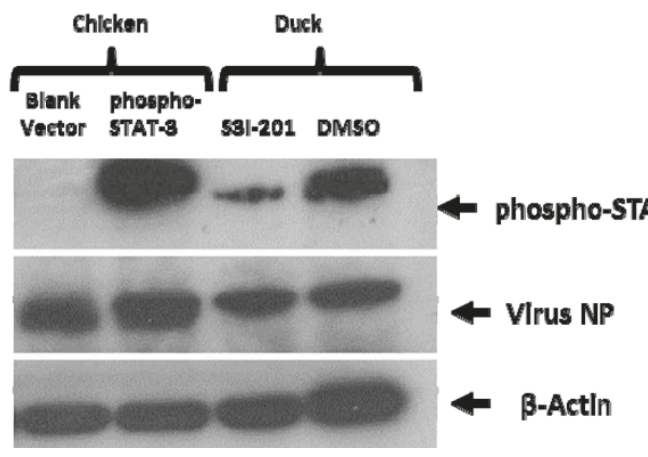

Chicken

B

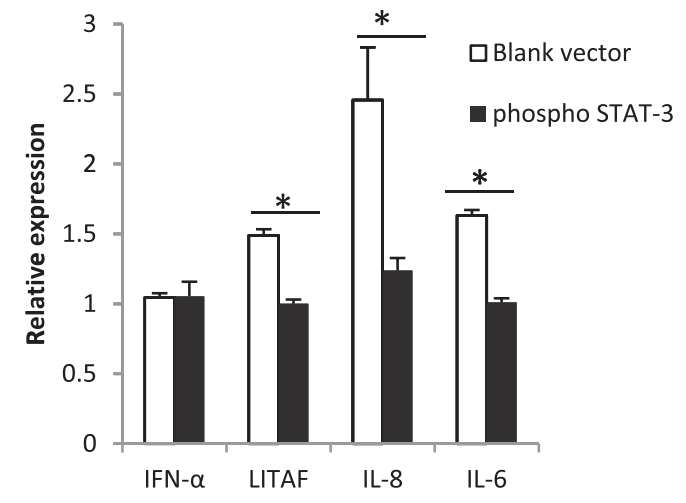

D

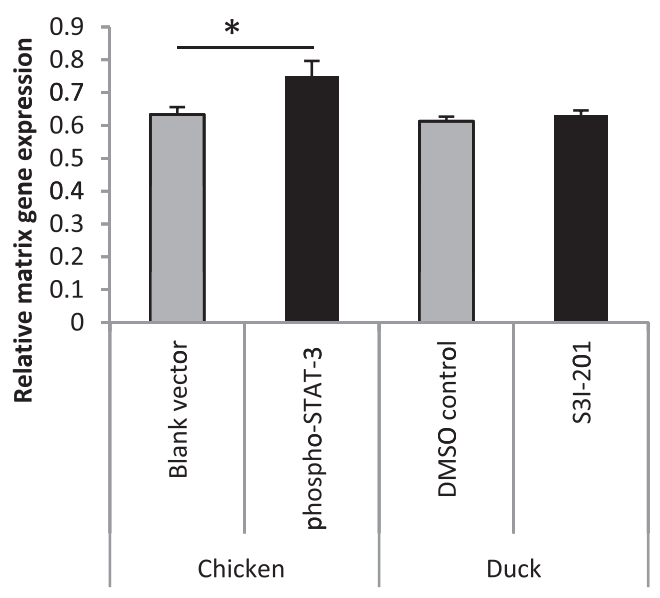

Duck

C

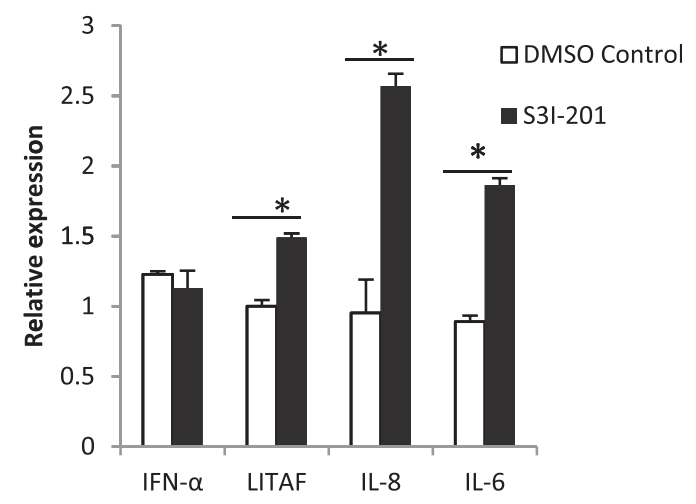

E

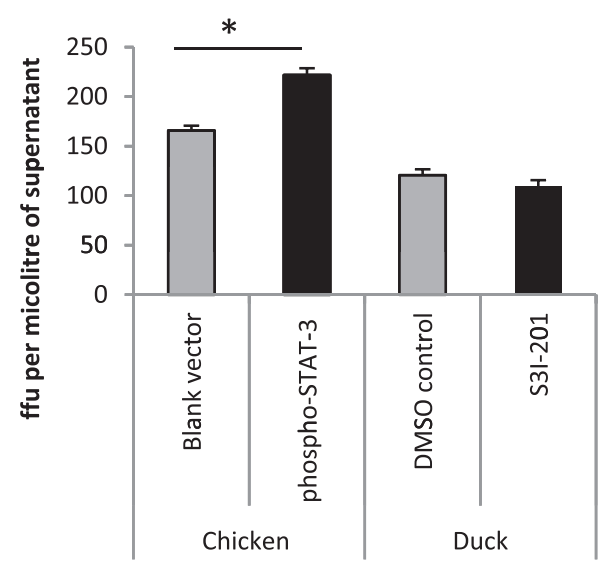

Figure 8 STAT-3 appears to regulate the pro-inflammatory response and promote virus replication in H5N1 virus infected chicken and duck cells. (A) Primary chicken embryo cells over-expressing phospho-STAT-3 showed a high phospho-STAT-3 expression while STAT-3 inhibitor S3l-201 treatment resulted in reduced phospho-STAT-3 protein expression in duck cells at $24 \mathrm{~h}$ following H5N1-tyEng91 virus infection (1.0 MOI). (B) phospho-STAT-3 over-expressing chicken cells showed a significant reduction in LITAF, IL6 and IL-8 mRNA expression with no significant change in IFN-a expression. (C) At $24 \mathrm{~h}$ following H5N1-tyEng91 virus infection, in STAT-3 inhibited duck primary embryo cells, significant increase of LITAF, IL-8 and IL-6 mRNA expression was detected with no significant change in IFN-a expression. Phospho STAT-3 over-expression in chicken cells increased viral replication at $24 \mathrm{~h}$ following H5N1-tyEng91 virus infection as evidenced by increased detection of virus NP (A), matrix gene mRNA (D) and infectious virus output in culture supernatant (E). STAT-3 inhibition did not significantly affect virus NP (A) matrix gene expression (D) or infectious virus production (E) at $24 \mathrm{~h}$ following H5N1-tyEng91 virus infection in duck cells. Relative mRNA expression was determined by real-time PCR to $18 \mathrm{~S}$ rRNA. Data points are the mean of three biological replicates with error bars as standard deviation $\left(^{*} p<0.05\right)$. 
down-regulation of $I L-18$ in H5N1virus infected chicken cells correlated with reduced pSTAT-3 detection.

Chicken cells over-expressing constitutively active STAT-3 showed significantly lower LITAF, IL-6 and IL-8 mRNA levels compared with the blank plasmid transfected cells at 24 h post H5N1-tyEng91 virus infection. Duck cells treated with S3I-201 that inhibits the transcriptional activity of STAT-3, resulted in increased expression of LITAF, IL-6 and $I L-8$ compared with control cells at 24 h post H5N1tyEng91 virus infection. Previous studies showed that constitutively active STAT3 can suppress both $I L-6$ and $T N F-\alpha$ production in lipopolysaccharide-stimulated macrophages [66]. The sum of this evidence raise a strong possibility that STAT-3 mediated gene transcription could play a central role in suppressing pro-inflammatory responses during $\mathrm{H} 5 \mathrm{~N} 1$ virus infection in ducks. Furthermore the ability of HPAI viruses to inhibit STAT-3 in chickens correlates with excessive pro-inflammatory response and the development of fatal disease. Further studies would help to identify candidate genes that suppress pro-inflammation during HPAI H5N1 virus infection and are transcriptionally regulated by STAT- 3 .

Surprisingly, we found that STAT-3 over-expression significantly increased H5N1 HPAI virus replication in chicken cells while STAT-3 inhibition had no significant effect on virus replication in duck cells. The increase in influenza virus replication in chicken cells over-expressing STAT-3 could be due to inhibition of type I IFN-mediated antiviral response. However, STAT-3 over-expression or inhibition did not significantly affect IFN- $\alpha$ mRNA expression in chicken and duck cells respectively. Conversely, STAT3 has been suggested as an important upstream element in type I IFN signal transduction and in the induction of antiviral activities [62]. The role of STAT-3 in virus replication appears to be complex. For example STAT-3 induction promotes varicella-zoster virus replication [67], activates anti-hepatitis $\mathrm{C}$ virus $(\mathrm{HCV})$ activity in liver cells [68] and promotes HCV RNA replication [69]. Findings of the present study suggest that STAT-3 could promote influenza virus replication in chicken cells but not in duck cells. We showed previously that duck cells produce significantly less infectious influenza virus compared with chicken cells which correlated with rapid cell death [20]. It is likely that other mechanisms independent of STAT- 3 could contribute to the antiviral effects observed in duck cells. As STAT-3 is a transcription factor and known to mediate the expression of a variety of genes, it is likely that STAT-3 over-expression or inhibition may affect a number of cellular signalling pathways. Hence, further studies are needed to identify candidate genes that play an important role in mediating pro-inflammation and influenza virus replication in chickens and ducks.

\section{Additional files}

Additional file 1: Preparation of RNA target and hybridization on to GeneChip expression arrays. Protocol describing sample preparation and hybridization on to Genechip and probe masking for cross species hybridization of duck RNA onto chicken Genechip.

Additional file 2: List of key immune related genes that were differentially regulated between chicken and duck cells following influenza virus infection. List of key immune related genes that were differentially regulated in chicken and duck cells following infection with LPAI H2N3, H5N1-tyEng91 and H5N1-tyTR05 viruses.

\section{Competing interests}

The authors declare that they have no competing interests.

\section{Authors' contributions}

Conceived and designed the experiments: SVK, SPD and KCC. Performed the experiments and microarray data analysis: SVK. In vivo challenge studies: BZ and SB (duck challenge experiments); CJ and LV (chicken challenge experiments). Planning and organization of HPAl infection experiments: SVK SB and IB. Analysed qPCR data: SVK, MT and SS. Contributed to the writing of the manuscript: SVK, KCC, SPD, SB, IB and LV. All authors read and approved the final manuscript.

\section{Acknowledgements}

We are grateful to colleagues at AHVLA for their valuable support, Fanny Garcon and Vivian Coward (technical assistance); Bethany Nash, Jonathan Ridgeon and Michael Kelly (laboratory support). This work was part funded by the BBSRC grant BB/E010849/1, the University of Nottingham (pump prime grant to SVK) and DEFRA grant SE0782 (BZL, SMB and IHB). In vivo chicken experiment: This study was financially supported by the Netherlands Organization for Scientific Research (NWO) Veni grant 016.096.049, the EU sixth framework program Flupath (grant 04220) and by the "Impulse Veterinary Avian Influenza Research in The Netherlands, Dutch Ministry of Agriculture, Nature and Food Quality (CAJ and LV).

\section{Author details}

${ }^{1}$ School of Veterinary Medicine and Science, University of Nottingham, Sutton Bonington Campus, College Road, Loughborough, Nottingham, Leicestershire LE12 5RD, UK. Virology Department, Animal and Plant Health Agency, Weybridge, Addlestone, Surrey KT15 3NB, UK. ${ }^{3}$ Department of Infectious Diseases and Immunology, Faculty of Veterinary Medicine, University of Utrecht, Utrecht, The Netherlands. ${ }^{4}$ Current address: The Roslin Institute and R(D)SVS, University of Edinburgh, Easter Bush, Midlothian, Edinburgh EH25 9RG, UK.

Received: 3 October 2014 Accepted: 31 October 2014

Published online: 28 November 2014

\section{References}

1. Gibbs AJ, Armstrong JS, Downie JC: From where did the 2009 'swine-origin' influenza A virus (H1N1) emerge? Virol J 2009, 6:207.

2. Thitithanyanont $A$, Engering $A$, Uiprasertkul $M$, Ekchariyawat $P$, Wiboon-Ut $S$, Kraivong R, Limsalakpetch A, Kum-Arb U, Yongvanitchit K, Sa-Ard-lam N, Rukyen P, Mahanonda R, Kawkitinarong K, Auewarakul P, Utaisincharoen P, Sirisinha S, Mason CJ, Fukuda MM, Pichyangkul S: Antiviral immune responses in $\mathrm{H} 5 \mathrm{~N} 1$-infected human lung tissue and possible mechanisms underlying the hyperproduction of interferon-inducible protein IP-10. Biochem Biophys Res Commun 2010, 398:752-758.

3. Katz JM, Veguilla V, Belser JA, Maines TR, Van Hoeven N, Pappas C, Hancock K, Tumpey TM: The public health impact of avian influenza viruses. Poult Sci 2009, 88:872-879.

4. Sharp GB, Kawaoka Y, Jones DJ, Bean WJ, Pryor SP, Hinshaw V, Webster RG: Coinfection of wild ducks by influenza $A$ viruses: distribution patterns and biological significance. J Virol 1997, 71:6128-6135.

5. Isoda N, Sakoda Y, Kishida N, Bai GR, Matsuda K, Umemura T, Kida H: Pathogenicity of a highly pathogenic avian influenza virus, $A /$ chicken/ Yamaguchi/7/04 (H5N1) in different species of birds and mammals. Arch Virol 2006, 151:1267-1279. 
6. Perkins LEL, Swayne DE: Pathogenicity of a Hong Kong-origin H5N1 highly pathogenic avian influenza virus for emus, geese, ducks, and pigeons. Avian Dis 2002, 46:53-63

7. Jeong OM, Kim MC, Kim MJ, Kang HM, Kim HR, Kim YJ, Joh SJ, Kwon JH, Lee YJ: Experimental infection of chickens, ducks and quails with the highly pathogenic H5N1 avian influenza virus. J Vet Sci 2009, 10:53-60.

8. Saito T, Watanabe C, Takemae N, Chaisingh A, Uchida Y, Buranathai C, Suzuki H, Okamatsu M, Imada T, Parchariyanon S, Traiwanatam N, Yamaguchi S: Pathogenicity of highly pathogenic avian influenza viruses of $\mathrm{H} 5 \mathrm{~N} 1$ subtype isolated in Thailand for different poultry species. Vet Microbiol 2009, 133:65-74.

9. Chen HY, Shang YH, Yao HX, Cui BA, Zhang HY, Wang ZX, Wang YD, Chao AJ, Duan TY: Immune responses of chickens inoculated with a recombinant fowlpox vaccine coexpressing $\mathrm{HA}$ of $\mathrm{H} 9 \mathrm{~N} 2$ avain influenza virus and chicken IL-18. Antiviral Res 2011, 91:50-56.

10. Guan Y, Peiris M, Kong KF, Dyrting KC, Ellis TM, Sit T, Zhang $\sqcup$, Shortridge KF: H5N1 influenza viruses isolated from geese in Southeastern China: evidence for genetic reassortment and interspecies transmission to ducks. Virology 2002, 292:16-23.

11. Wibawa $H$, Henning J, Wong F, Selleck $P$, Junaidi A, Bingham J, Daniels $P$, Meers J: A molecular and antigenic survey of H5N1 highly pathogenic avian influenza virus isolates from smallholder duck farms in Central Java, Indonesia during 2007-2008. Virol J 2011, 8:425.

12. Londt BZ, Nunez A, Banks J, Nili H, Johnson LK, Alexander DJ: Pathogenesis of highly pathogenic avian influenza A/turkey/Turkey/1/2005 H5N1 in Pekin ducks (Anas platyrhynchos) infected experimentally. Avian Pathol 2008, 37:619-627.

13. Ramos I, Fernandez-Sesma A: Innate immunity to H5N1 influenza viruses in humans. Viruses 2012, 4(12):3363-3388.

14. Cheung CY, Poon LL, Lau AS, Luk W, Lau YL, Shortridge KF, Gordon S, Guan Y Peiris JS: Induction of proinflammatory cytokines in human macrophages by influenza $A$ ( $\mathrm{H} 5 \mathrm{~N} 1)$ viruses: a mechanism for the unusual severity of human disease? Lancet 2002, 360:1831-1837.

15. Lipatov AS, Andreansky S, Webby RJ, Hulse DJ, Rehg JE, Krauss S, Perez DR, Doherty PC, Webster RG, Sangster MY: Pathogenesis of Hong Kong H5N1 influenza virus NS gene reassortants in mice: the role of cytokines and B- and T-cell responses. J Gen Virol 2005, 86:1121-1130.

16. Lipatov AS, Kwon YK, Sarmento LV, Lager KM, Spackman E, Suarez DL, Swayne DE: Domestic pigs have low susceptibility to H5N1 highly pathogenic avian influenza viruses. PLoS Pathog 2008, 4:e1000102.

17. Nelli RK, Dunham SP, Kuchipudi SV, White GA, Baquero-Perez B, Chang P, Ghaemmaghami A, Brookes SM, Brown IH, Chang KC: Mammalian innate resistance to highly pathogenic avian influenza $\mathrm{H} 5 \mathrm{~N} 1$ virus infection is mediated through reduced proinflammation and infectious virus release. J Virol 2012, 86:9201-9210.

18. Cornelissen JB, Vervelde L, Post J, Rebel JM: Differences in highly pathogenic avian influenza viral pathogenesis and associated early inflammatory response in chickens and ducks. Avian Pathol 2013, 42:347-364.

19. Wood GW, Parsons G, Alexander DJ: Replication of influenza A viruses of high and low pathogenicity for chickens at different sites in chickens and ducks following intranasal inoculation. Avian Pathol 1995, 24:545-551.

20. Kuchipudi SV, Dunham SP, Nelli R, White GA, Coward VJ, Slomka MJ, Brown $\mathrm{H}$, Chang KC: Rapid death of duck cells infected with influenza: a potential mechanism for host resistance to H5N1. Immunol Cell Biol 2012, 90:116-123.

21. Irizarry RA, Hobbs B, Collin F, Beazer-Barclay YD, Antonellis KJ, Scherf U, Speed TP: Exploration, normalization, and summaries of high density oligonucleotide array probe level data. Biostatistics 2003, 4:249-264.

22. Irizarry RA, Bolstad BM, Collin F, Cope LM, Hobbs B, Speed TP: Summaries of Affymetrix GeneChip probe level data. Nucleic Acids Res 2003, 31:e15.

23. da Huang W, Sherman BT, Lempicki RA: Systematic and integrative analysis of large gene lists using DAVID bioinformatics resources. Nat Protoc 2009, 4:44-57

24. da Huang W, Sherman BT, Lempicki RA: Bioinformatics enrichment tools: paths toward the comprehensive functional analysis of large gene lists. Nucleic Acids Res 2009, 37:1-13.

25. Hammond JP, Broadley MR, Craigon DJ, Higgins J, Emmerson ZF, Townsend HJ, White PJ, May ST: Using genomic DNA-based probe-selection to improve the sensitivity of high-density oligonucleotide arrays when applied to heterologous species. Plant Methods 2005, 1:10.

26. X-species Version 2.1 [http://affymetrix.arabidopsis.info/xspecies/]
27. CDF_masking.Zip [http://affymetrix.arabidopsis.info/xspecies/CDF_masking.zip]

28. Siddiquee K, Zhang S, Guida WC, Blaskovich MA, Greedy B, Lawrence HR, Yip ML, Jove R, McLaughlin MM, Lawrence NJ, Sebti SM, Turkson J: Selective chemical probe inhibitor of Stat3, identified through structure-based virtual screening, induces antitumor activity. Proc Natl Acad Sci U S A 2007, 104:7391-7396.

29. Pfaffl MW, Horgan GW, Dempfle L: Relative expression software tool (REST) for group-wise comparison and statistical analysis of relative expression results in real-time PCR. Nucleic Acids Res 2002, 30:e36.

30. Expression data from low- and high-pathogenicity avian influenza-infected chicken and duck cells. [http://www.ncbi.nlm.nih.gov/geo/query/acc.cgi? acc=GSE33389]

31. Moody DE, Zou Z, McIntyre L: Cross-species hybridisation of pig RNA to human nylon microarrays. BMC Genomics 2002, 3:27.

32. Crowley TM, Haring VR, Burggraaf S, Moore RJ: Application of chicken microarrays for gene expression analysis in other avian species. BMC Genomics 2009, 10(Suppl 2):S3.

33. Anderson PW, Tennant BC, Lee Z: Cross-species hybridization of woodchuck hepatitis virus-induced hepatocellular carcinoma using human oligonucleotide microarrays. World J Gastroenterol 2006, 12:4646-4651.

34. Malone $\mathrm{JH}$, Oliver $\mathrm{B}$ : Microarrays, deep sequencing and the true measure of the transcriptome. BMC Biol 2011, 9:34

35. Sarmento L, Afonso CL, Estevez C, Wasilenko J, Pantin-Jackwood M: Differentia host gene expression in cells infected with highly pathogenic $\mathrm{H} 5 \mathrm{~N} 1$ avian influenza viruses. Vet Immunol Immunopathol 2008, 125:291-302.

36. Kobasa D, Jones SM, Shinya K, Kash JC, Copps J, Ebihara H, Hatta Y, Kim JH, Halfmann P, Hatta M, Feldmann F, Alimonti JB, Fernando L, Li Y, Katze MG Feldmann $\mathrm{H}$, Kawaoka $\mathrm{Y}$ : Aberrant innate immune response in lethal infection of macaques with the 1918 influenza virus. Nature 2007, 445:319-323.

37. Chan MC, Cheung CY, Chui WH, Tsao SW, Nicholls JM, Chan YO, Chan RW, Long HT, Poon LL, Guan Y, Peiris JS: Proinflammatory cytokine responses induced by influenza A (H5N1) viruses in primary human alveolar and bronchial epithelial cells. Respir Res 2005, 6:135.

38. Kaiser L, Fritz RS, Straus SE, Gubareva L, Hayden FG: Symptom pathogenesis during acute influenza: interleukin- 6 and other cytokine responses. J Med Virol 2001, 64:262-268.

39. Kim B, Ahn KK, Ha Y, Lee YH, Kim D, Lim JH, Kim SH, Kim MY, Cho KD, Lee BH, Chae C: Association of tumor necrosis factor-alpha with fever and pulmonary lesion score in pigs experimentally infected with swine influenza virus subtype H1N2. J Vet Med Sci 2009, 71:611-616.

40. Hong YH, Lillehoj HS, Lee SH, Park D, Lillehoj EP: Molecular cloning and characterization of chicken lipopolysaccharide-induced TNF-alpha factor (LITAF). Dev Comp Immunol 2006, 30:919-929.

41. Reemers SS, Groot Koerkamp MJ, Holstege FC, van Eden W, Vervelde L. Cellular host transcriptional responses to influenza $A$ virus in chicken tracheal organ cultures differ from responses in in vivo infected trachea. Vet Immunol Immunopathol 2009, 132:91-100.

42. Reemers SS, van Haarlem DA, Groot Koerkamp MJ, Vervelde L: Differential gene-expression and host-response profiles against avian influenza virus within the chicken lung due to anatomy and airflow. J Gen Virol 2009, 90:2134-2146.

43. Karpala AJ, Bingham J, Schat KA, Chen LM, Donis RO, Lowenthal JW, Bean AG: Highly pathogenic ( $\mathrm{H} 5 \mathrm{~N} 1)$ avian influenza induces an inflammatory $\mathrm{T}$ helper type 1 cytokine response in the chicken. J Interferon Cytokine Res 2011, 31:393-400.

44. Huang Y, Li Y, Burt DW, Chen H, Zhang Y, Qian W, Kim H, Gan S, Zhao Y, Li J, Yi K, Feng H, Zhu P, Li B, Liu Q, Fairley S, Magor KE, Du Z, Hu X, Goodman L, Tafer H, Vignal A, Lee T, Kim KW, Sheng Z, An Y, Searle S, Herrero J, Groenen MA, Crooijmans RP, et al: The duck genome and transcriptome provide insight into an avian influenza virus reservoir species. Nat Genet 2013, 45:776-783.

45. Vanderven HA, Petkau K, Ryan-Jean KE, Aldridge JR Jr, Webster RG, Magor KE: Avian influenza rapidly induces antiviral genes in duck lung and intestine. Mol Immunol 2012, 51:316-324.

46. Barber MR, Aldridge JR Jr, Webster RG, Magor KE: Association of RIG-I with innate immunity of ducks to influenza. Proc Natl Acad Sci U S A 2010, 107:5913-5918.

47. Adams SC, Xing Z, Li J, Cardona CJ: Immune-related gene expression in response to $\mathrm{H} 11 \mathrm{~N} 9$ low pathogenic avian influenza virus infection in chicken and Pekin duck peripheral blood mononuclear cells. Mol Immunol 2009, 46:1744-1749 
48. Liniger M, Summerfield A, Zimmer G, McCullough KC, Ruggli N: Chicken cells sense influenza $A$ virus infection through MDA5 and CARDIF signaling involving LGP2. J Virol 2012, 86:705-717.

49. Tian Y, Chen WL, Ou JH: Effects of interferon-alpha/beta on HBV replication determined by viral load. PLoS Pathog 2011, 7:e1002159.

50. de Jong MD, Simmons CP, Thanh TT, Hien VM, Smith GJ, Chau TN, Hoang DM, Chau NV, Khanh TH, Dong VC, Qui PT, Cam BV, Ha do Q, Guan Y, Peiris JS, Chinh NT, Hien TT, Farrar J: Fatal outcome of human influenza A (H5N1) is associated with high viral load and hypercytokinemia. Nat Med 2006, 12:1203-1207.

51. Peiris JS, Yu WC, Leung CW, Cheung CY, Ng WF, Nicholls JM, Ng TK, Chan KH, Lai ST, Lim WL, Yuen KY, Guan Y: Re-emergence of fatal human influenza A subtype H5N1 disease. Lancet 2004, 363:617-619.

52. To KF, Chan PK, Chan KF, Lee WK, Lam WY, Wong KF, Tang NL, Tsang DN, Sung RY, Buckley TA, Tam JS, Cheng AF: Pathology of fatal human infection associated with avian influenza A H5N1 virus. J Med Viro/ 2001, 63:242-246.

53. Cornelissen JB, Post J, Peeters B, Vervelde L, Rebel JM: Differential innate responses of chickens and ducks to low-pathogenic avian influenza. Avian Pathol 2012, 41:519-529.

54. Liu B, Mori I, Hossain MJ, Dong L, Takeda K, Kimura Y: Interleukin-18 improves the early defence system against influenza virus infection by augmenting natural killer cell-mediated cytotoxicity. J Gen Virol 2004, 85:423-428.

55. Bohn E, Sing A, Zumbihl R, Bielfeldt C, Okamura H, Kurimoto M, Heesemann J, Autenrieth IB: IL-18 (IFN-gamma-inducing factor) regulates early cytokine production in, and promotes resolution of, bacterial infection in mice. J Immunol 1998, 160:299-307.

56. Fujioka N, Akazawa R, Ohashi K, Fujii M, Ikeda M, Kurimoto M: Interleukin-18 protects mice against acute herpes simplex virus type 1 infection. J Virol 1999, 73:2401-2409.

57. Kawakami K, Qureshi MH, Zhang T, Okamura H, Kurimoto M, Saito A: IL-18 protects mice against pulmonary and disseminated infection with Cryptococcus neoformans by inducing IFN-gamma production. J Immunol 1997, 159:5528-5534.

58. Sugawara I, Yamada H, Kaneko H, Mizuno S, Takeda K, Akira S: Role of interleukin-18 (IL-18) in mycobacterial infection in IL-18-gene-disrupted mice. Infect Immun 1999, 67:2585-2589.

59. Jansen CA, de Geus ED, van Haarlem DA, van de Haar PM, Londt BZ, Graham SP, Gobel TW, van Eden W, Brookes SM, Vervelde L: Differential lung NK cell responses in avian influenza virus infected chickens correlate with pathogenicity. Sci Rep 2013, 3:2478.

60. $\mathrm{Ho} \mathrm{HH}$, Ivashkiv LB: Role of STAT3 in type I interferon responses. Negative regulation of STAT1-dependent inflammatory gene activation. J Biol Chem 2006, 281:14111-14118.

61. Hazari S, Chandra PK, Poat B, Datta S, Garry RF, Foster TP, Kousoulas G, Wakita T, Dash S: Impaired antiviral activity of interferon alpha against hepatitis $C$ virus $2 a$ in Huh-7 cells with a defective Jak-Stat pathway. Virol J 2010, 7:36.

62. Yang $\mathrm{CH}$, Murti A, Pfeffer LM: STAT3 complements defects in an interferon-resistant cell line: evidence for an essential role for STAT3 in interferon signaling and biological activities. Proc Natl Acad Sci U S A 1998, 95:5568-5572.

63. Paulson M, Pisharody S, Pan L, Guadagno S, Mui AL, Levy DE: Stat protein transactivation domains recruit p300/CBP through widely divergent sequences. J Biol Chem 1999, 274:25343-25349.

64. El Kasmi KC, Holst J, Coffre M, Mielke L, de Pauw A, Lhocine N, Smith AM, Rutschman R, Kaushal D, Shen Y, Suda T, Donnelly RP, Myers MG Jr, Alexander W, Vignali DA, Watowich SS, Ernst M, Hilton DJ, Murray PJ: General nature of the STAT3-activated anti-inflammatory response. J Immunol 2006, 177:7880-7888.

65. Kalina U, Kauschat D, Koyama N, Nuernberger H, Ballas K, Koschmieder S, Bug G, Hofmann WK, Hoelzer D, Ottmann OG: IL-18 activates STAT3 in the natural killer cell line 92, augments cytotoxic activity, and mediates IFN-gamma production by the stress kinase $\mathrm{p} 38$ and by the extracellular regulated kinases p44erk-1 and p42erk-21. J Immunol 2000, 165:1307-1313.

66. Williams LM, Sarma U, Willets K, Smallie T, Brennan F, Foxwell BM: Expression of constitutively active STAT3 can replicate the cytokine-suppressive activity of interleukin-10 in human primary macrophages. J Biol Chem 2007, 282:6965-6975.
67. Sen N, Che X, Rajamani J, Zerboni L, Sung P, Ptacek J, Arvin AM: Signal transducer and activator of transcription 3 (STAT3) and survivin induction by varicella-zoster virus promote replication and skin pathogenesis. Proc Natl Acad Sci U S A 2012, 109:600-605.

68. Zhu H, Shang X, Terada N, Liu C: STAT3 induces anti-hepatitis C viral activity in liver cells. Biochem Biophys Res Commun 2004, 324:518-528.

69. Waris G, Turkson J, Hassanein T, Siddiqui A: Hepatitis C virus (HCV) constitutively activates STAT-3 via oxidative stress: role of STAT-3 in HCV replication. J Virol 2005, 79:1569-1580.

\section{doi:10.1186/s13567-014-0118-3}

Cite this article as: Kuchipudi et al:: Highly pathogenic avian influenza virus infection in chickens but not ducks is associated with elevated host immune and pro-inflammatory responses. Veterinary Research 2014 45:118.

\section{Submit your next manuscript to BioMed Central and take full advantage of:}

- Convenient online submission

- Thorough peer review

- No space constraints or color figure charges

- Immediate publication on acceptance

- Inclusion in PubMed, CAS, Scopus and Google Scholar

- Research which is freely available for redistribution 